\title{
Perancangan Tata Letak Lantai Produksi Baru dengan Metode Systematic Layout Planning
}

\section{Production Layout Design Using Systematic Layout Planning Method}

\author{
Retty Chate rin Siahaan, Teguh Oktiarso \\ Universitas Ma Chung \\ E-mail: 411210023@student.machung.ac.id, teguh.oktiarso@ machung.ac.id
}

\begin{abstract}
Abstrak
CV. Ika Raya Sentausa adalah industri yang bergerak dalam bidang makanan. Produk yang dihasilkan yaitu saus sambal, saus manis, kecap, dan tepung tapioka. Area pabrik terdiri dari kantor utama, lantai produksi, dan packing tepung tapioka. Pemilik ingin memindahkan area lantai produksi ke area packing tepung tapioka dikarenakan jumlah produksi saus sambal, saus manis, dan kecap belum mencapai target penjualan perusahaan. Selain itu, luas packing lantai produksi saat ini masih belum dimaksimakanl. Berdasarkan masalah tersebut digunakan metode Systematic Layout Planning supaya dapat menghitung luas lantai produksi yang dibutuhkan pada area baru, membantu perusahaan dalam mengusulkan layout alternatif baru pada area packing tepung tapioka dan memilih jarak aliran material terkecil dari produksi saus sambal, manis, dan kecap. Pada layout lantai produksi saat ini, jarak aliran material pada saus sebesar 78,53 m dan kecap sebesar 108,45 m dengan luas sebesar $830 \mathrm{~m}^{2}$. Setelah melakukan langkah-langkah dalam metode Systematic Layout, maka dibuat tiga alternatif layout usulan yang memiliki jarak aliran material lebih kecil dibanding awal. Diantara ketiga layout, terpilihlah layout alternatif III karena memiliki jarak aliran material yang lebih sesuai dibanding usulan lainnya dengan jarak aliran material saus sebesar 77,3689725 m dan kecap sebesar 62,08776 m dengan luas yang dibutuhkan sebesar 1.056,44255 $\mathrm{m}^{2}$.

Kata kunci: Jarak Aliran Material, Kebutuhan Luas Area, Systematic Layout Planning.
\end{abstract}

\begin{abstract}
CV. Ika Raya Sentausa is one of food industry which produces chilli sauce, sweet sauce, soy sauce, and tapioca flour. The factory area consists of main office, production floor, and tapioca flour packing. The owner wants to move the old production floor area to tapioca flour packing area because the number of production of chilli sauce, sweet sauce, and soy sauce not in accordance with company's sales target. Moreover, spacious packing of production is still not maximum yet. Based on this case, Systematic Layout Planning method will be used to count the production floor in the new area, help the company for making alternative layout, and choose the smallest material flow distance of production. Material flow distance of the old layout production are 78,53 $\mathrm{m}$ for sauces and 108,45 $\mathrm{m}$ for soy sauce. The space is $830 \mathrm{~m}^{2}$. After doing the step of Systematic Layout Planning, three alternative layouts have been decided. Space requirement is 1.056,44255 $\mathrm{m}^{2}$. The new alternative layouts have smaller material flow distance than the old one. Alternative layout III has been chosen as the best choice between the other alternative layouts. The alternative layout III material flow distance are 77,3689725 $\mathrm{m}$ for the sauces and 62,0877 $\mathrm{m}$ for soy sauce.

Keywords: Material Flow Distance, Space Area Requirement, Systematic Layout Planning
\end{abstract}

\section{Pendahuluan}

Industri makanan adalah salah satu industri penting di Indonesia khususnya di Jawa Timur. Hal ini dikarenakan masyarakat telah banyak mengonsumsi makanan dari berbagai produk sehingga menyebabkan persaingan ketat antara pelaku industri makanan. Adanya persaingan yang ketat membuat pelaku industri makanan harus meningkatkan kualitas maupun kuantitas produknya. Peningkatan kuantitas produksi dapat dilakukan dengan menaikkan jumlah produksinya agar dapat dipasok ke berbagai wilayah Jawa Timur.

CV. Ika Raya Sentausa ( CV. IKS) adalah perusahaan yang bergerak dalam manufaktur makanan. Luas pabrik keseluruhan yaitu $4.000 \mathrm{~m}^{2}$ yang dibagi menjadi area kantor utama, lantai produksi 


\section{PERANCANGAN TATA LETAK LANTAI PRODUKS I B ARU (Retty C. S., dkk)}

(saus sambal, saus manis, dan kecap), dan packing tepung tapioka. Luas area lantai produksi saat ini adalah $830 \mathrm{~m}^{2}$, sedangkan area packing tepung tapioka adalah $1.140 \mathrm{~m}^{2}$. Pemilik memiliki rencana untuk memindahkan area lantai produksi saat ini ke area packing tepung tapioka. Pemindahan area dilakukan karena jumlah produksi saus sambal, saus manis, dan kecap belum mencapai target penjualan perusahaan serta luas area lantai produksi saat ini masih belum maksimal. Untuk mencapai target penjualan di perlukan perombakan pada area produksi agar dapat meningkatkan kapasitas produksi.

Berdasarkan permasalahan tersebut, maka dibutuhkan metode yang dapat mengatasi permasalahan yang terjadi pada perusahaan. Metode Systematic Layout Planning (SLP) merupakan metode yang dipilih supaya dapat membantu perusahaan dalam menghitung luas area yang dibutuhkan pada area baru, membuat alternatif layout, dan menghitung jarak aliran material terkecil pada layout saat ini dengan layout usulan. Metode SLP dipilih untuk menyelesaikan permasalahan di CV. IKS karena metode SLP cocok untuk jenis produksi di CV. IKS yang cenderung ke arah flow production system.

Tujuan dari penelitian ini adalah menentukan luas lantai produksi yang diperlukan pada area produksi baru serta merancang tata letak pabrik yang baru pada CV. Ika Raya Sentausa agar jarak tempuh aliran material area lantai produksi baru lebih pendek dibandingkan dengan lantai produksi lama sehingga jumlah produksi bisa meningkat sesuai dengan target penjualan.

\section{Tinjauan Pustaka}

Perancangan fasilitas merupakan salah satu kegiatan pendukung produksi yang terdapat pada perusahaan manufaktur. Terdapat dua klasifikasi pada perancangan fasilitas yaitu perencanaan lokasi dan perancangan fasilitas. Perencanaan lokasi berkaitan dengan proses penentuan daerah atau tempat untuk melakukan kegiatan pada perusahaan baik produksi atau manajerial. Sementara itu, perancangan fasilitas berkaitan dengan pembangunan fasilitas sebagai penunjang kegiatan perusahaan sesuai dengan tujuan aktivitas (Hadiguna dkk, 2008).

Beberapa tujuan dari perencanaan fasilitas pabrik adalah melancarkan proses produksi dalam manufaktur sehingga tidak ada hal yang mengganggu proses produks inya, meminimalkan pemindahan barang, mengurangi biaya pada material handling, mengatur setiap perpindahan dalam pekerjaan yang dilakukan, memanfaatkan bangunan dari lokasi yang telah dilakukan secara ekonomis, menambah penggunaan sumber daya yang tersedia, serta mengurangi adanya kecelakaan sehingga dapat meningkatkan tingkat keselamatan dan kesehatan kerja para pekerja (Apple, 1990).

Perhitungan jarak antar area dapat dilakukan dengan metode jarak rectilinear. Pengukuran jarak dengan menggunakan jarak rectilinear (atau dapat disebut juga dengan jarak Manhattan, right angle, atau rectangular metric) mengikuti aturan garis tegak lurus. Metode jarak rectilinear banyak digunakan karena mudah dipahami dan digunakan dalam memecahkan permasalahan jarak (Chandry, 2006).

Pengukuran jarak menggunakan metode rectilinear tidak memperhatikan adanya lintasan atau aisle sehingga pengukuran dilakukan menggunakan per titik tengah pada area produksi. Berikut adalah rumus yang digunakan dalam mengukur jarak rectilinear (Heragu, 1997; dalam Susetyo dkk, 2010):

$a_{i j}=\left|x_{i}-x_{j}\right|+\left|y_{i}-y_{j}\right|$

Pada rumus tersebut terdapat huruf $\mathrm{x}$ dan $\mathrm{y}$ yang menandakan koordinat titik berat pada bangun datar. Terdapat dua persamaan dalam mencari koordinat titik berat yaitu pada satu bidang datar dan dua bidang datar atau lebih. Persamaan koordinat titik berat pada satu bidang datar yaitu (Muliawan, 2008):

$x 1=b+\frac{a-b}{2}$ 
$y 1=a+\frac{c-d}{2}$

Sedangkan persamaan koordinat titik berat pada dua bidang datar atau lebih yaitu (Dewi dkk, 2012):

$x=\frac{A 1 \times x 1+A 2 \times x 2+\cdots+A n \times x n}{A 1+A 2+\cdots+A n}$
$y=\frac{A 1 \times y 1+A 2 \times y 2 \ldots+A n \times y_{n}}{A 1+A 2+\cdots+A n}$

Keterangan:

$\mathrm{x} 1$ dan $\mathrm{y} 1=$ koordinat $\mathrm{x}$ dan $\mathrm{y}$ pada bangun datar.

$\mathrm{a}$ dan $\mathrm{b}=$ koordinat sumbu $\mathrm{x}$ terbesar/terkecil pada bangun datar.

$\mathrm{c} \quad=$ koordinat sumbu y terbesar pada bangun datar.

$\mathrm{d} \quad=$ koordinat sumbu y terkecil pada bangun datar.

A $\quad=$ luas penampang pada bangun datar.

Terdapat sebuah metode dalam menghitung kebutuhan luas ruangan yaitu metode fasilitas industri. Metode tersebut membantu da lam perhitungan luas ruangan yang dihitung dari ukuran setiap mesin atau peralatan yang digunakan da lam proses produksi ditambah dengan allowance operator sebesar $50 \%$. Rumus yang digunakan dalam metode fasilitas industri adalah (Purnomo, 2004; dalam Naganingrum, 2012):

Luas ruangan $=($ ukuran setiap mesin dan perlatan $\mathrm{x}$ jumlah mesin $)+$ allowance operator

Teknik dalam pengimplementasian tata letak pabrik memiliki banyak ragam untuk melakukan perencanaan tata letak pabrik. Salah satu metode yang digunakan untuk merencanakan dan merancang pabrik adalah metode Systematic Layout Planning. Metode ini memiliki beberapa prosedur dalam perencanaan tata letak pabrik (Yuliarty dkk, 2014).

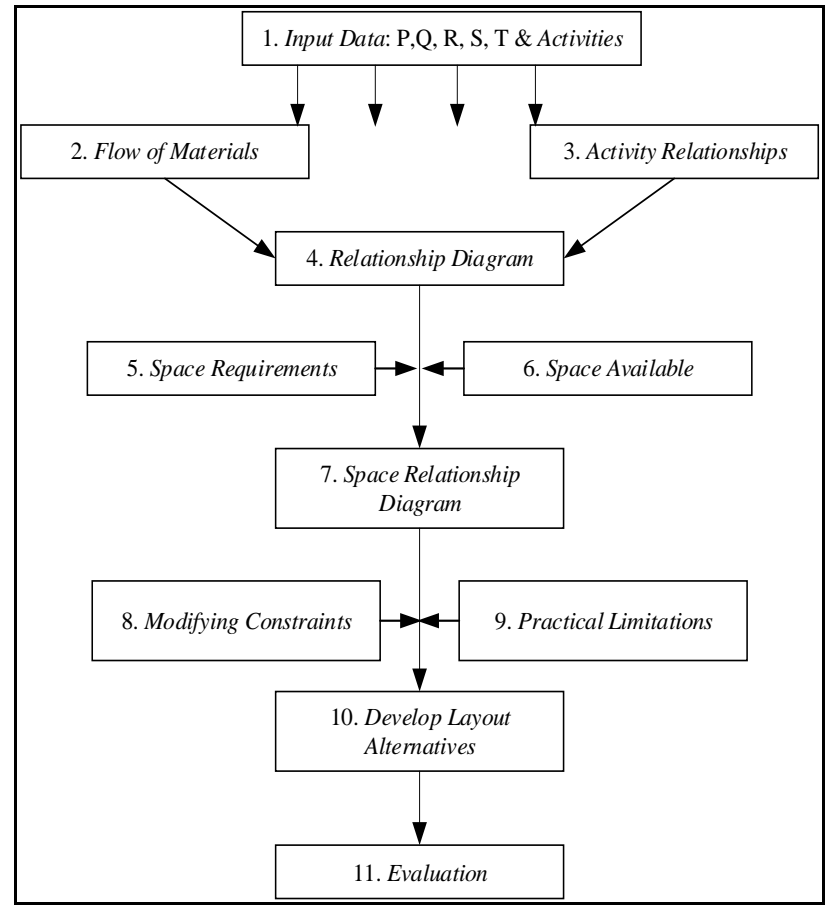

Gambar 1. Langkah-langkah Metode Systematic Layout Planning (Yang dkk, 2000)

Tata letak usulan yang akan dibuat menggunakan metode Systematic Layout Planning dengan melakukan tahap-tahap sebagai berikut (Yang dkk,2000):

1. Pembuatan lima input dalam metode SLP yaitu $\mathrm{P}, \mathrm{Q}, \mathrm{R}, \mathrm{S}$, dan $\mathrm{T}$..

2. Identifikasi terhadap aliran material proses produksi pada setiap departemen atau kegiatan yang berhubungan dengan operasional. 


\section{PERANCANGAN TATA LETAK LANTAI PRODUKS I B ARU (Retty C. S., dkk)}

3. Identifikasi activity relationship chart atau ARC. Grafik hubungan aktivitas akan menentukan derajat hubungan antar departemen dengan memperhatikan dua aspek yaitu kualitatif dan kuantitatif.

4. Pembuatan activity relationship diagram yang akan menghubungkan derajat hubungan aktivitas serta aliran material yang terdapat dalam produksi.

5. Identifikasi terhadap kebutuhan luas area untuk mengatur segala fasilitas pabrik yang dibutuhkan.

6. Identifikasi luas ruangan yang tersedia supaya dapat disesuaikan dengan luas bangunan pabrik yang telah ada.

7. Pembuatan hubungan antar ruangan dengan menggunakan space relationship diagram. Evaluasi terhadap luas area yang dibutuhkan dilakukan dalam langkah ini. Diagram ini dapat dilakukan setelah proses analisis terhadap luas area yang dibutuhkan dikombinasikan terhadap activity relationship diagram.

8. Pembuatan modifying constraints

9. Pembuatan practical limitations dilakukan pertimbangan secara praktis untuk memodifikasi layout.

10. Pengembangan alternatif layout

11. Pengevaluasian terhadap usulan layout untuk memberikan keyakinan terhadap keputusan dari beberapa alternatif yang diberikan sudah optimal.

\section{Pembahasan}

Pada bab ini akan dijabarkan tentang pengumpulan data terdiri dari data jadwal kerja karyawan, kapasitas produksi, proses produksi, layout awal area produksi dan area packing tepung tapioka saat ini, Bill of Material dari produk saus dan kecap, serta jumlah mesin dan peralatan. Input PQRST pada penelitian ini yaitu data jadwal kerja karyawan, kapasitas produksi, BOM, proses produksi, dan jumlah mesin dan peralatan. Pengolahan data akan dilakukan setelah data awalan telah dikumpulkan.

\subsection{Pengumpulan Data}

\subsubsection{Data Jadwal Kerja Karyawan}

Waktu kerja karyawan pada CV. Ika Raya Sentausa selama 6 hari dalam satu minggu. Pekerjaan dimulai pada pukul 07:00 setiap harinya. Waktu selesai bekerja dalam satu minggu berbeda-beda. Dibawah ini merupakan rincian jadwal kerja pada CV. Ika Raya Sentausa:

Tabel 1. Jadwal Kerja Karyawan

\begin{tabular}{|c|c|c|}
\hline Hari & $\begin{array}{c}\text { Waktu } \\
\text { Ke rja }\end{array}$ & $\begin{array}{c}\text { Waktu } \\
\text { Is tirahat }\end{array}$ \\
\cline { 1 - 1 } Senin & & \\
\cline { 1 - 1 } Selasa & & \\
\cline { 1 - 1 } Rabu & $07: 00-15: 30$ & \multirow{2}{*}{$11: 45-12: 30$} \\
\cline { 1 - 1 } Kamis & & \\
\cline { 1 - 1 } Jumat & \\
\cline { 1 - 1 } Sabtu & $07: 00-14: 30$ \\
\cline { 1 - 1 } Minggu & \multicolumn{2}{|c|}{ LIBUR } \\
\hline
\end{tabular}

\subsubsection{Data Kapasitas Produksi dan BOM}

Kapasitas produksi merupakan salah satu hal yang penting dalam melakukan perancangan tata letak pada pabrik ini karena berpengaruh dalam BOM produk. Kapasitas produksi diasumsikan berdasarkan dari jumlah produksi terbesar dari produksi saus sambal, saus manis, dan kecap dalam 20 bulan (mulai Mei 2014 hingga Desember 2015). 
Pada saus sambal jumlah produksi yang terbesar yaitu bulan Juni 2015 sehingga kapasitas produksinya dapat mencapai 19.606 ball (1 ball = 24 buah; per buah $500 \mathrm{~g})$. Saus man is memiliki jumlah produksi yang terbesar yaitu bulan Januari 2015 sehingga kapasitas produksinya dapat mencapai 26.286 ball. Kecap memiliki jumlah produksi yang terbesar yaitu bulan Juni 2015 sehingga kapasitas produksinya dapat mencapai 8.575 ball (1 ball $=24$ buah; per buah $450 \mathrm{~g}$ ).

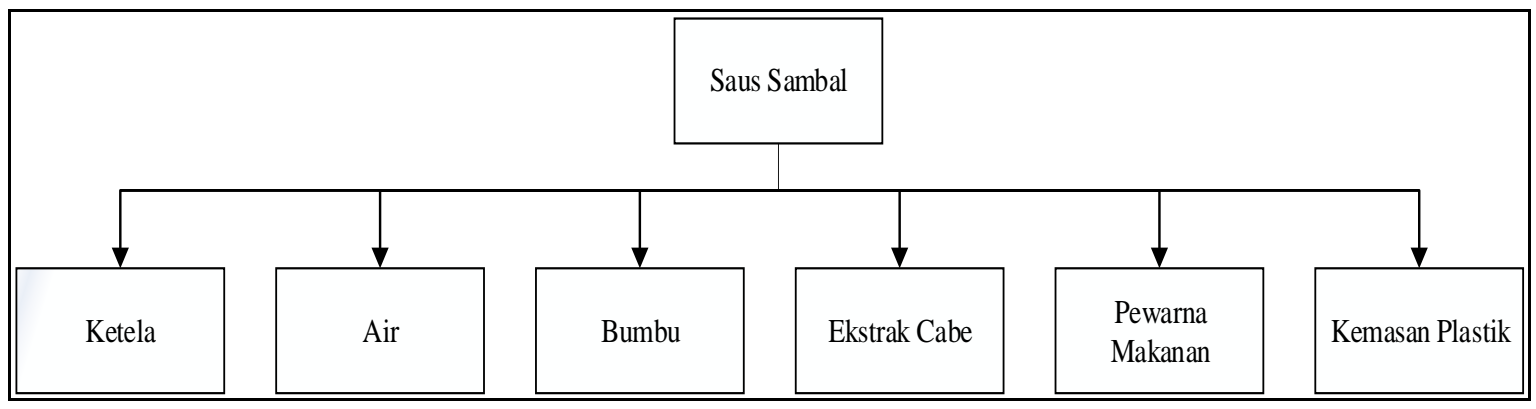

Gambar 2. BOM Saus Sambal

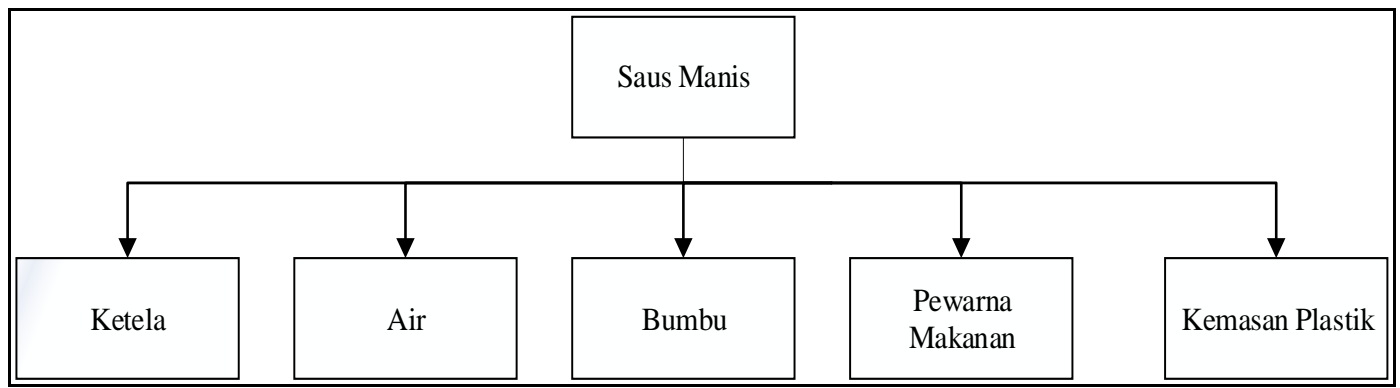

Gambar 3. BOM Saus Manis

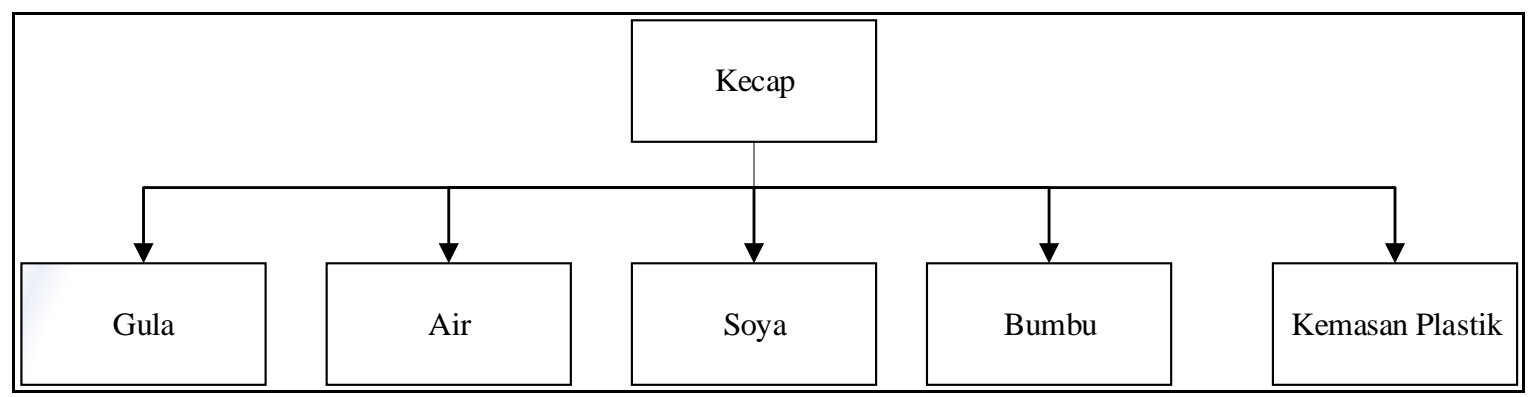

Gambar 4. BOM Kecap

\subsubsection{Data Proses Produksi}

Tahapan-tahapan proses produksi saus sambal dan manis yaitu (saus sambal dan manis memiliki proses produksi yang sama. Perbedaan terletak pada jenis bumbunya):

a. Penampungan Awal dan Penyortiran Ketela

b. Pencucian Ketela

c. Pemotongan Ketela

d. Pembilasan Ketela

e. Pemasakan Awal Ketela

f. Penghalusan Ketela

g. Pemasakan Akhir Ketela

h. Pengepakan Saus 
Proses produksi kecap pada CV Ika Raya Sentausa adalah sebagai berikut:

a. Pencampuran Bahan Baku

b. Pemasakan Bahan Baku

c. Pengepakan Kecap

\subsubsection{Jumlah dan Ukuran Mesin/Peralatan}

Dalam memproduksi saus sambal, manis, dan kecap dibutuhkan mes in dan peralatan sebagai salah satu penunjang kegiatan produksi. Mesin dan peralatan membantu kegiatan produksi dalam mengolah bahan mentah menjadi barang jadi. Jumlah dan ukuran mesin memiliki pengaruh dalam menentukan kebutuhan ruangan yang akan dilakukan dalam pengolahan data.

Tabel 2. Ju mlah Mesin dan Peralatan

\begin{tabular}{|c|c|c|c|}
\hline No & Nama Area & Nama Mesin dan Pe ralatan & Jumlah \\
\hline 1 & \multirow{7}{*}{$\begin{array}{c}\text { Area Penyimpanan } \\
\text { dan Penimbangan } \\
\text { ketela }\end{array}$} & Mesin Pencuci Ketela & 1 \\
\hline 2 & & Konveyor Mesin Pencuci & 1 \\
\hline 3 & & Mesin Pembilas & 1 \\
\hline 4 & & Konveyor Mesin Pembilas & 1 \\
\hline 5 & & Mesin Pemotong atau Perajang & 1 \\
\hline 6 & & Konveyor Mesin Pemotong atau Perajang & 1 \\
\hline 7 & & Keranjang & 7 \\
\hline 8 & \multirow{23}{*}{$\begin{array}{l}\text { Area Produksi Saus } \\
\text { Sambal dan Manis }\end{array}$} & Tangga Kecil & 6 \\
\hline 9 & & Mesin Penghalus Ketela & 1 \\
\hline 10 & & $\begin{array}{l}\text { Wadah Besar (untuk produksi saus dan } \\
\text { kecap) }\end{array}$ & 22 \\
\hline 11 & & Motor Penggerak & 17 \\
\hline 12 & & $\begin{array}{l}\text { Motor Penggerak Pipa } \\
\end{array}$ & 13 \\
\hline 13 & & $\begin{array}{c}\text { Wadah Besar (untuk produksi saus dan } \\
\text { kecap) }\end{array}$ & 3 \\
\hline 14 & & Motor Penggerak & 1 \\
\hline 15 & & Motor Penggerak Pipa & 1 \\
\hline 16 & & Tangga Kecil & 1 \\
\hline 17 & & Wadah Plastik B iru Besar & 2 \\
\hline 18 & & Wadah Stainless Besar & 2 \\
\hline 19 & & Mesin Packing & 2 \\
\hline 20 & & Meja Sealed Kecil & 1 \\
\hline 21 & & Meja Sealed Besar & 1 \\
\hline 22 & & Kursi Sealed & 4 \\
\hline 23 & & Meja Timbangan & 1 \\
\hline 24 & & Meja Kompor & 1 \\
\hline 25 & & LPG & 1 \\
\hline 26 & & Wadah Plastik Biru Kecil & 17 \\
\hline 27 & & Mesin Packing & 7 \\
\hline 28 & & Wadah Stainless & 7 \\
\hline 29 & & Wadah Packing Kecil & 7 \\
\hline 30 & & Wadah Plastik Biru Besar & 1 \\
\hline
\end{tabular}


Tabel 2. Ju mlah Mesin dan Peralatan (Lanjutan)

\begin{tabular}{|c|c|c|c|}
\hline No & Nama Area & Nama Mesin dan Peralatan & Jumlah \\
\hline 31 & \multirow{27}{*}{$\begin{array}{c}\text { Area Gudang Bahan } \\
\text { Baku }\end{array}$} & Meja Operator Gudang & 2 \\
\hline 32 & & Palet Kuning & 10 \\
\hline 33 & & Kursi Operator Gudang & 2 \\
\hline 34 & & Hand Tracker & 1 \\
\hline 35 & & Meja Kantor & 1 \\
\hline 36 & & Lemari Kecil (Kantor Produksi) & 1 \\
\hline 37 & & Lemari Besar (Kantor Produksi) & 2 \\
\hline 38 & & Kursi Kantor & 1 \\
\hline 39 & & Rak Kantor Produksi & 1 \\
\hline 40 & & Kotak Penyimpanan Plastik & 1 \\
\hline 41 & & Lemari Besar (Kantor Maintenance) & 1 \\
\hline 42 & & Lemari Kecil (Kantor Maintenance) & 2 \\
\hline 43 & & Meja Kantor & 2 \\
\hline 44 & & Kursi Kantor & 2 \\
\hline 45 & & Rak Biru Penyimpan Sparepart & 1 \\
\hline 46 & & Rak Bengkel Besar & 1 \\
\hline 47 & & Mesin Bubut & 1 \\
\hline 48 & & Rak Bengkel Kecil & 1 \\
\hline 49 & & Rak Seng & 1 \\
\hline 50 & & Meja Kantor & 3 \\
\hline 51 & & Kursi Kantor & 3 \\
\hline 52 & & Dapur Besar (Laboratorium) & 1 \\
\hline 53 & & Kulkas & 1 \\
\hline 54 & & $\mathrm{AC} /$ Pendingin & 1 \\
\hline 55 & & Rak (Laboratorium) & 1 \\
\hline 56 & & Dapur Kecil (Laboratorium) & 1 \\
\hline 57 & & Palet Kuning & 4 \\
\hline
\end{tabular}

Tabel 3. Ukuran Mesin dan Peralatan

\begin{tabular}{|c|c|c|c|c|c|}
\hline \multirow{2}{*}{ No } & \multirow{2}{*}{ Nama Mesin dan Pe ralatan } & \multicolumn{4}{|c|}{ Ukuran (m) } \\
\cline { 3 - 6 } & & Panjang & Lebar & Diameter & Tinggi \\
\hline 1 & Keranjang & 0,59 & 0,4 & - & - \\
\hline 2 & Tangga Kecil & 0,735 & 0,59 & - & - \\
\hline 3 & Mesin Penghalus Ketela & 1,1 & 0,87 & - & - \\
\hline 4 & Wadah Plastik Biru Kecil & - & - & 0,35 & 0,56 \\
\hline 5 & Wadah Plastik Biru Besar & - & - & 0,99 & 1,16 \\
\hline 6 & Wadah Plastik Biru Sedang & - & - & 0,58 & 0,9 \\
\hline 7 & Palet Kuning & 1,22 & 1 & - & - \\
\hline 8 & Rak Biru Penyimpan & 0,99 & 0,4 & - & - \\
\hline 9 & Sparepart & 0,57 & 0,4 & - & - \\
\hline 10 & Keranjang Packing & 1,6 & 0,76 & - & - \\
\hline 11 & Hand Tracker & 5,39 & 1,16 & - & - \\
\hline 12 & Konin Pencuci Ketela & 2,34 & 0,86 & - & - \\
\hline 13 & Menveyor Mesin Pencuci & 3,32 & 0,81 & - & - \\
\hline
\end{tabular}


PERANCANGAN TATA LETAK LANTAI PRODUKS I B ARU (Retty C. S., dkk)

Tabel 3 Ukuran Mesin dan Peralatan (Lanjutan)

\begin{tabular}{|c|c|c|c|c|c|}
\hline \multirow{2}{*}{ No } & \multirow{2}{*}{ Nama Mesin dan Peralatan } & \multicolumn{4}{|c|}{ Ukuran (m) } \\
\hline & & Panjang & Lebar & Diame ter & Tinggi \\
\hline 14 & Konveyor Mesin Pembilas & 1,85 & 0,48 & - & - \\
\hline 15 & Mesin Pemotong & 1,51 & 1,1 & - & - \\
\hline 16 & $\begin{array}{c}\text { Konveyor Mesin Pemotong } \\
\text { atau Perajang }\end{array}$ & 2,2 & 0,57 & - & - \\
\hline 17 & $\begin{array}{l}\text { Wadah Besar (untuk produksi } \\
\text { saus dan kecap) }\end{array}$ & - & - & 2,36 & 1,56 \\
\hline 18 & Motor Penggerak & 0,34 & 0,24 & - & - \\
\hline 19 & Motor Penggerak Pipa & 0,515 & 0,5 & - & - \\
\hline 20 & Wadah Packing Kecil & - & - & 0,655 & 1,16 \\
\hline 21 & Meja Kompor & $\overline{0,6}$ & 0,38 & - & - \\
\hline 22 & LPG & - & - & 0,27 & 0,59 \\
\hline 23 & Meja Sealed Kecil & 0,91 & 0,54 & - & - \\
\hline 24 & Meja Sealed Besar & 1 & 0,78 & - & - \\
\hline 25 & Kursi Sealed & 0,47 & 0,3 & - & - \\
\hline 26 & Meja Operator Gudang & 1,2 & 0,58 & - & - \\
\hline 27 & Kursi Operator Gudang & 0,39 & 0,37 & - & - \\
\hline 28 & Mesin Packing & 0,83 & 0,61 & - & - \\
\hline 29 & Wadah Stainless & - & - & 1,25 & 2,25 \\
\hline 30 & Rak Bengkel Besar & 2 & 0,6 & - & - \\
\hline 31 & Mesin Bubut & 0,72 & 0,57 & - & - \\
\hline 32 & Rak Bengkel Kecil & 0,66 & 0,5 & - & - \\
\hline 33 & Rak Seng & 5,56 & 0,57 & - & - \\
\hline 34 & Meja Kantor & 1,2 & 0,6 & - & - \\
\hline 35 & $\begin{array}{l}\text { Lemari Kecil (Kantor } \\
\text { Produksi) }\end{array}$ & 0,475 & 0,38 & - & - \\
\hline 36 & $\begin{array}{l}\text { Lemari Besar (Kantor } \\
\text { Produksi) }\end{array}$ & 0,88 & 0,4 & - & - \\
\hline 37 & Kursi Kantor & 0,42 & 0,38 & - & - \\
\hline 38 & Rak Kantor Produksi & 1,4 & 0,34 & - & - \\
\hline 39 & Kotak Penyimpanan Plastik & 0,65 & 0,48 & - & - \\
\hline 40 & $\begin{array}{c}\text { Lemari Besar (Kantor } \\
\text { Maintenance) }\end{array}$ & 1,6 & 0,44 & - & - \\
\hline 41 & $\begin{array}{c}\text { Lemari Kecil (Kantor } \\
\text { Maintenance) }\end{array}$ & 0,88 & 0,4 & - & - \\
\hline 42 & Dapur Besar (Laboratorium) & 3,6 & 0,61 & - & - \\
\hline 43 & Kulkas & 0,52 & 0,51 & - & - \\
\hline 44 & $\mathrm{AC} /$ Pendingin & 0,43 & 0,34 & - & - \\
\hline 45 & Rak (Laboratorium) & 0,65 & 0,45 & - & - \\
\hline 46 & Dapur Kecil (Laboratorium) & 1,77 & 0,6 & - & - \\
\hline 47 & Meja Timbangan & 0,38 & 0,32 & - & - \\
\hline 48 & Wadah Plastik Biru Panjang & - & - & 0,56 & 0,9 \\
\hline
\end{tabular}




\subsubsection{Data Layout Awal AreaLantai Produksi dan Area Packing Tepung Tapioka}

Lantai produksi saat ini memiliki 11 area yang terdiri dari area penyimpanan dan penimbangan ketela, laboratorium, produksi saus sambal dan saus manis, produksi kecap, packing, kantor produksi, gudang bahan baku, gudang penyimpanan gula, kantor maintenance, bengkel, dan toilet.

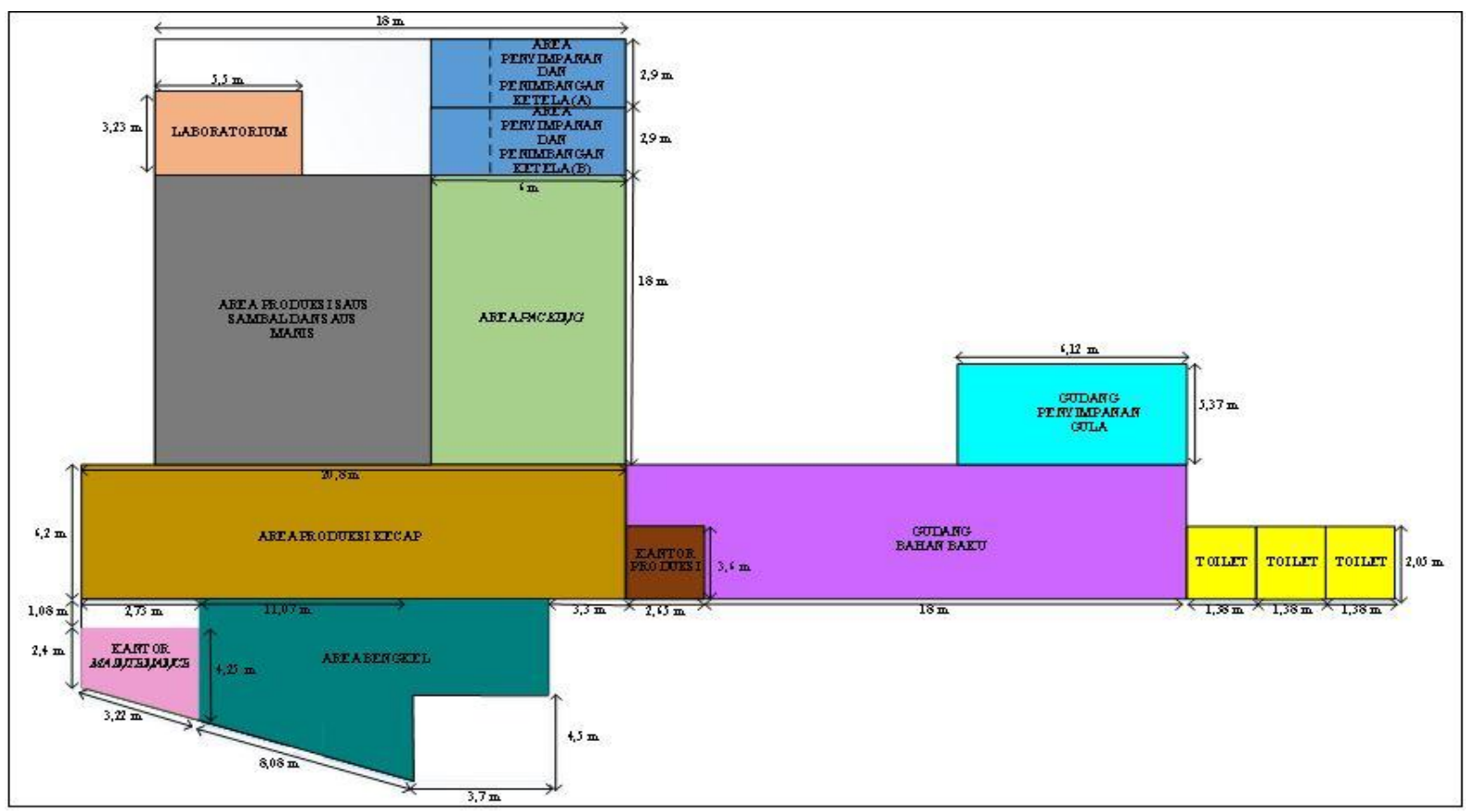

Gambar 5. Layout Lantai Produksi Saat Ini

\subsection{Identifikasi Aliran Mate rial}

Identifikasi aliran material dilakukan supaya dapat memahami dan mengerti aliran material yang digunakan pada proses produksi pada saus (sambal dan manis) serta kecap. Produk saus memiliki aliran material yang mencakup area penyimpanan dan penimbangan ketela, proses produksi saus sambal dan manis, laboratorium, dan packing. Produk kecap memiliki aliran material yang mencakup area gudang penyimpanan gula, produks i kecap, laboratorium, dan packing .

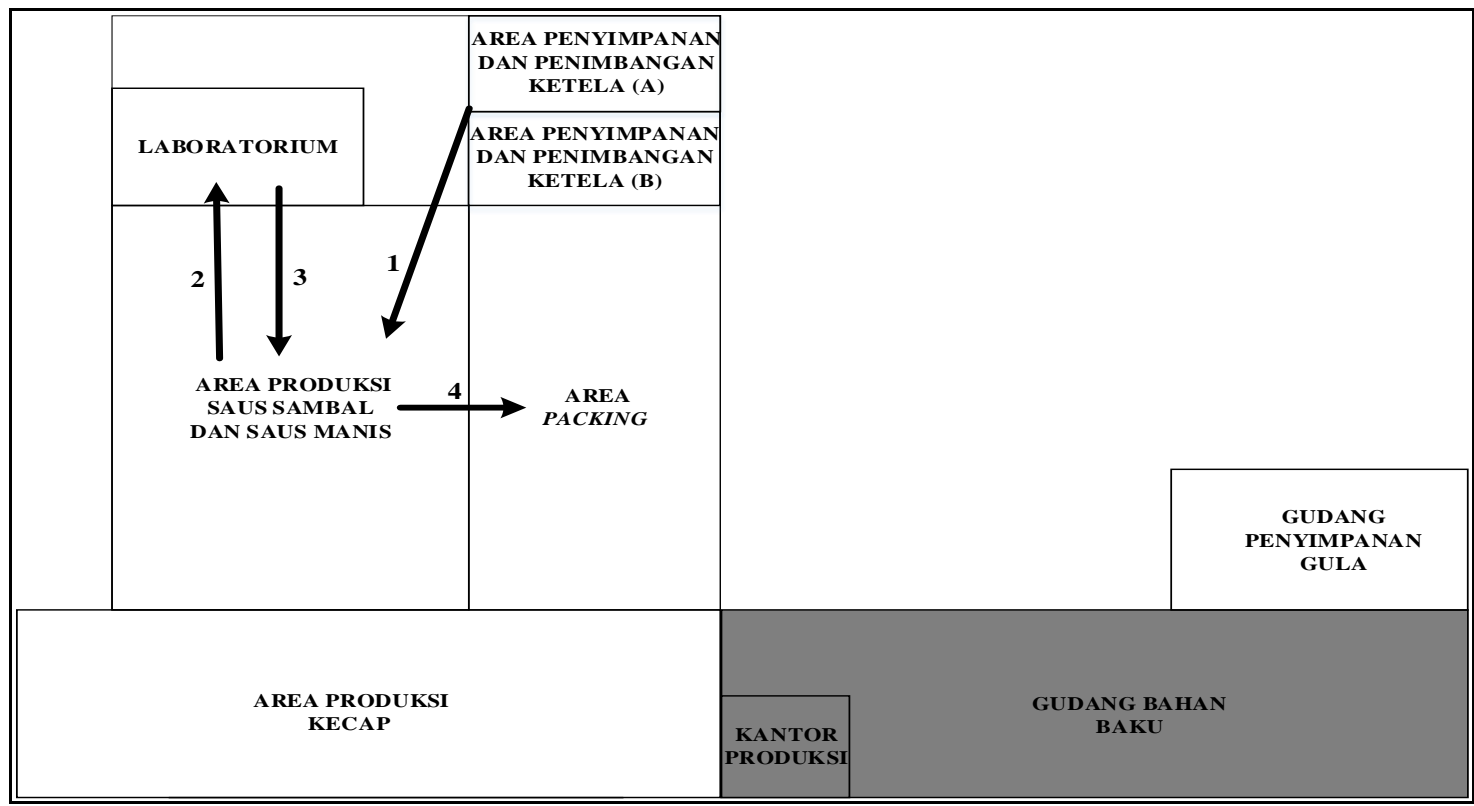

Gambar 6 Identifikasi A liran Material Saus Sambal dan Manis 


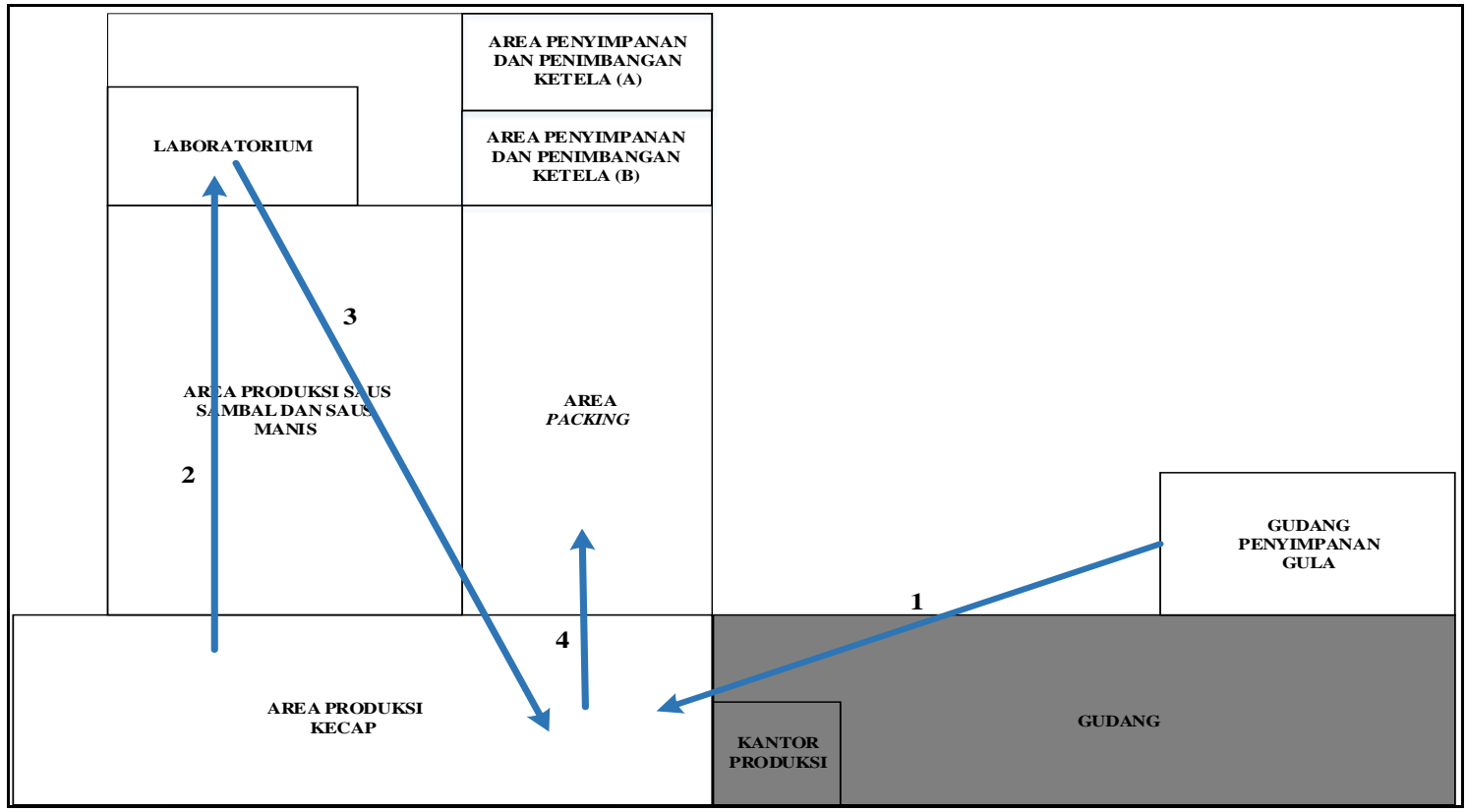

Gambar 7. Identifikasi Aliran Material Kecap

\subsubsection{Jarak Aliran Mate rial}

Penentuan jarak aliran material dilakukan dengan menentukan titik koordinat terlebih dahulu. Hal ini dikarenakan agar mempermudah perhitungan jarak aliran materialnya.

Tabel 4. Jarak Aliran Material Produksi Saus

\begin{tabular}{|c|c|c|}
\hline No & Nama Area & Jarak \\
\hline 1 & Area A ke C & $22,35 \mathrm{~m}$ \\
\hline 2 & Area B ke C & $19,45 \mathrm{~m}$ \\
\hline 3 & Area C ke D & $13,865 \mathrm{~m}$ \\
\hline 4 & Area D ke C & $13,865 \mathrm{~m}$ \\
\hline 5 & Area E ke C & $9 \mathrm{~m}$ \\
\hline \multicolumn{2}{|c|}{ Total } & $\mathbf{7 8 , 5 3 ~ m}$ \\
\hline
\end{tabular}

Tabel 5 Jarak A liran Material Produksi Kecap

\begin{tabular}{|c|c|c|}
\hline No & Nama Area & Jarak \\
\hline 1 & Area G ke F & $33,775 \mathrm{~m}$ \\
\hline 2 & Area F ke D & $27,565 \mathrm{~m}$ \\
\hline 3 & Area D ke F & $27,565 \mathrm{~m}$ \\
\hline 4 & Area F ke D & $19,5 \mathrm{~m}$ \\
\hline \multicolumn{2}{|c|}{ Total } & $\mathbf{1 0 8 , 4 0 5} \mathbf{~ m}$ \\
\hline
\end{tabular}

\subsection{Penentuan Activity Relationship Chart}

Activity Relationship Chart bertujuan agar memahami hubungan kedekatan per antar area aktivitas. Hal-hal yang mempengaruhi kedekatan tersebut disebabkan beberapa faktor antara lain hubungan aliran material, departemen yang berjauhan, mesin dan peralatan yang digunakan, dan lain-lain. Perolehan ARC didapatkan dari hasil wawancara dengan manajer produksi di CV. Ika Raya Sentausa. 


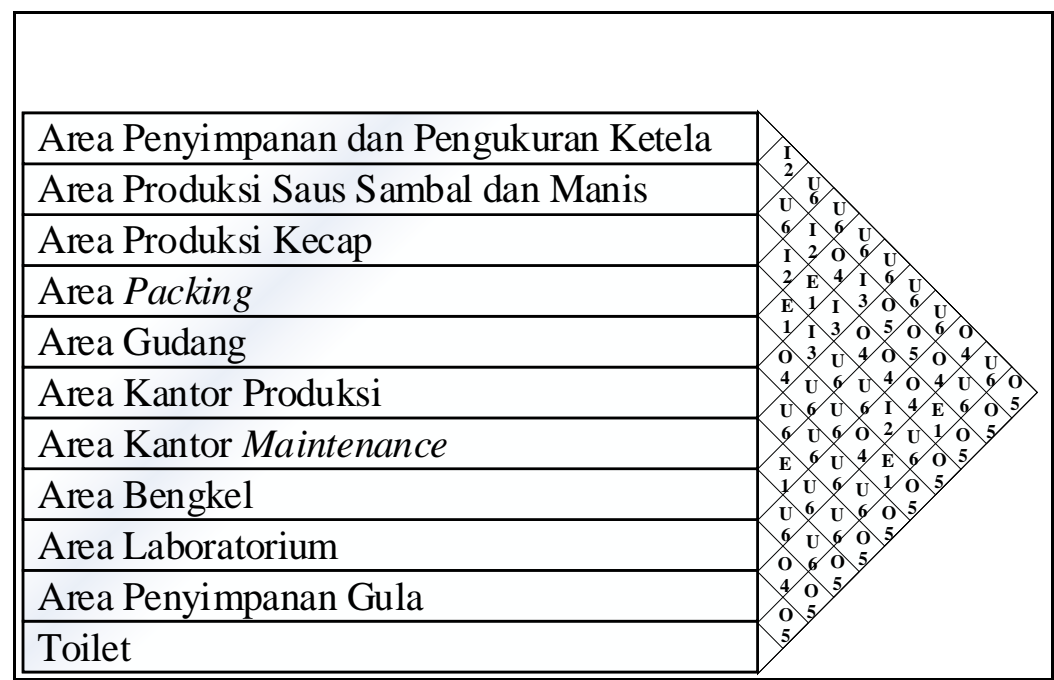

Gambar 8. ARC Lantai Produksi

Tabel 6. Alasan Kedekatan ARC

\begin{tabular}{|c|c|}
\hline Angka & Alasan Kedekatan \\
\hline 1 & Urutan Aliran Kerja \\
\hline 2 & Hemat dan efisien \\
\hline 3 & Kontrol lebih mudah \\
\hline 4 & Tidak berpengaruh \\
\hline 5 & Harus dipisah \\
\hline 6 & Aliran Kerja Tidak Sesuai \\
\hline
\end{tabular}

\subsection{Penentuan Activity Relationship Diagram}

ARD digambarkan dengan menghubungkan garis-garis sesuai dengan tingkat kedekatan per area yang sesuai dengan ARC yang telah dibuat.

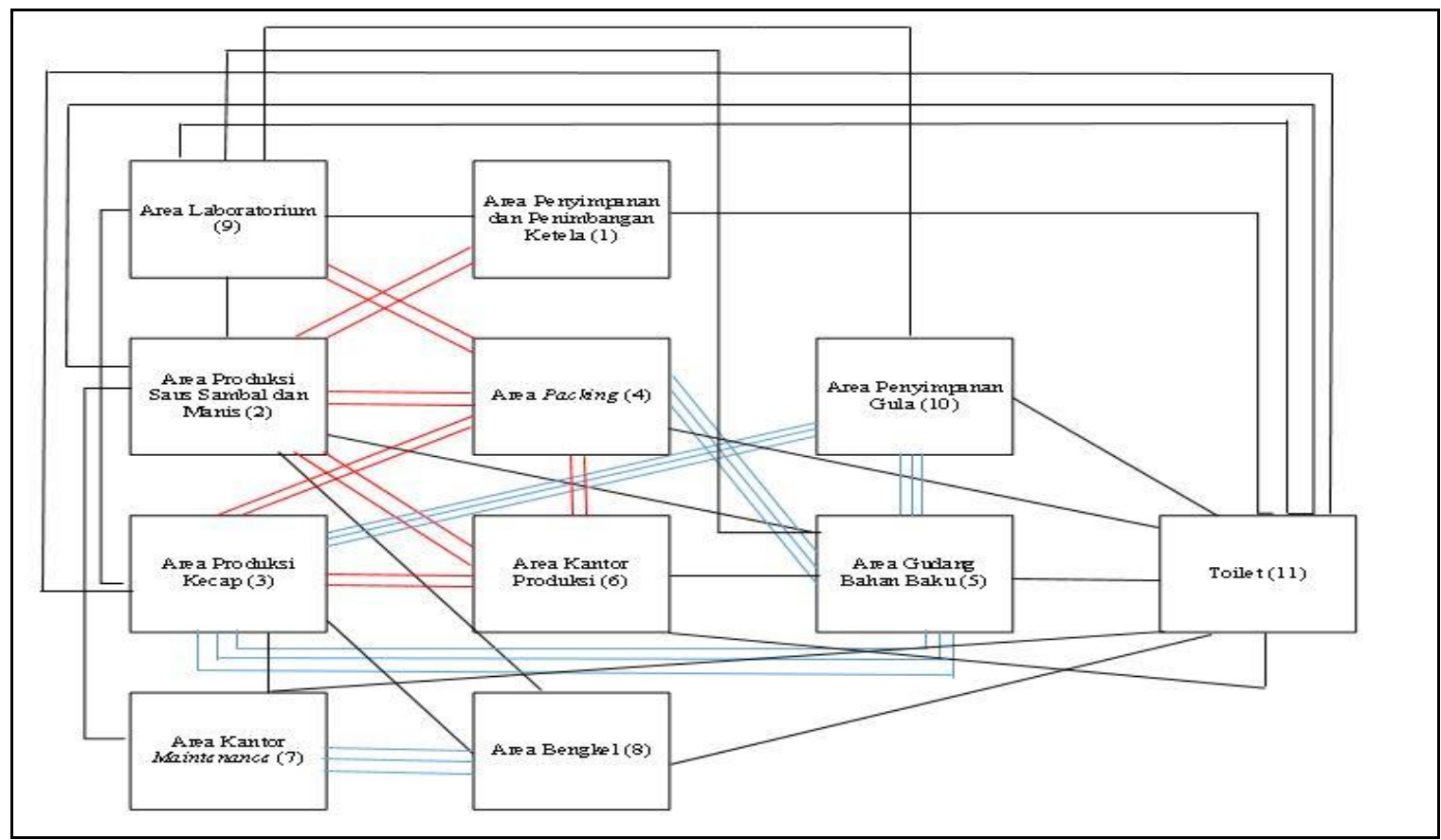

Gambar 9. ARD Keseluruhan Pada Lantai Produksi 


\subsection{Penentuan Kebutuhan Luas Ruangan}

Hal-hal yang dijadikan dasar dalam menentukan kebutuhan luas ruangan adalah jumlah mesin dan peralatan, ukuran mesin dan peralatan, maupun pekerja yang bekerja pada setiap area. Perhitungan kebutuhan luas ruangan menggunakan metode fasilitas industri yang menentukan luas ruangan berdasarkan fasilitas produksi maupun pendukung produksi. Setiap mesin dan peralatan menggunakan toleransi $0,75-1 \mathrm{~m}$ dan allowance operator sebesar $50 \%$.

Tabel 7. Kebutuhan Luas Ruangan Per Area

\begin{tabular}{|c|c|}
\hline Nama Area & $\begin{array}{c}\text { Kebutuhan Luas } \\
\text { Ruangan }\left(\mathbf{m}^{\mathbf{2}}\right)\end{array}$ \\
\hline Area Penyimpanan dan Penimbangan Ketela & 67,66725 \\
\hline Area Produksi Saus Sambal dan Manis & 466,72965 \\
\hline Area Produksi Kecap & 183,23265 \\
\hline Area Packing & 130,476 \\
\hline Area Gudang Bahan Baku & 129,300525 \\
\hline Area Kantor Produksi & 19,72965 \\
\hline Area Kantor Maintenance & 21,71205 \\
\hline Area Bengkel & 26,6184 \\
\hline Area Laboratorium & 38,6223 \\
\hline Area Gudang Penyimpanan Gula & 20,685 \\
\hline Toilet & - \\
\hline Total & $\mathbf{1 1 0 4 , 7 7 3 4 7 5}$ \\
\hline
\end{tabular}

Area pack ing tepung tapioka memiliki luas sebesar $1.140 \mathrm{~m}^{2}$ sedangkan kebutuhan ruangannya yaitu $1104,773475 \mathrm{~m}^{2}$ sehingga luas ruangan yang dibutuhkan pada area baru mencukupi.

\subsection{Penentuan Space Relationship Diagram}

Space Relationship Diagram ini merupakan kombinasi antara ARC, ARD, dan kebutuhan luas ruangan. Diagram SRD berbentuk diagram usulan supaya mempermudah untuk pembuatan layout usulan. Area yang dibuat untuk SRD usulan adalah area kantor .maintenance, bengkel, packing, gudang bahan baku, dan penyimpanan gula. Ukuran blok pada SRD berdasarkan kebutuhan luas ruangannya. 
JOURNAL OF INTEGRATED S YSTEM VOL 1. NO.2, DESEMB ER 2018: 161-179

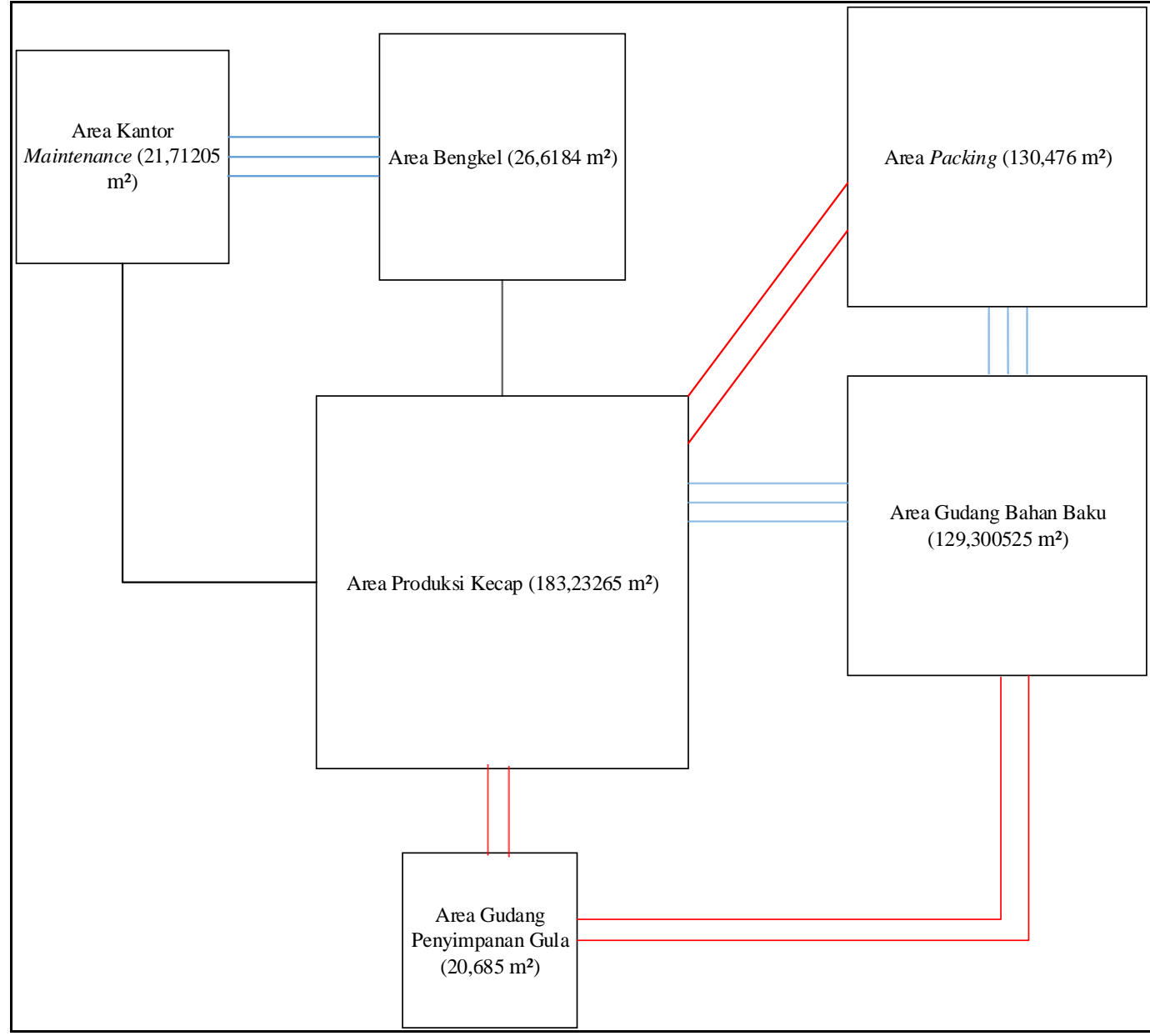

Gambar 10. SRD Usulan I

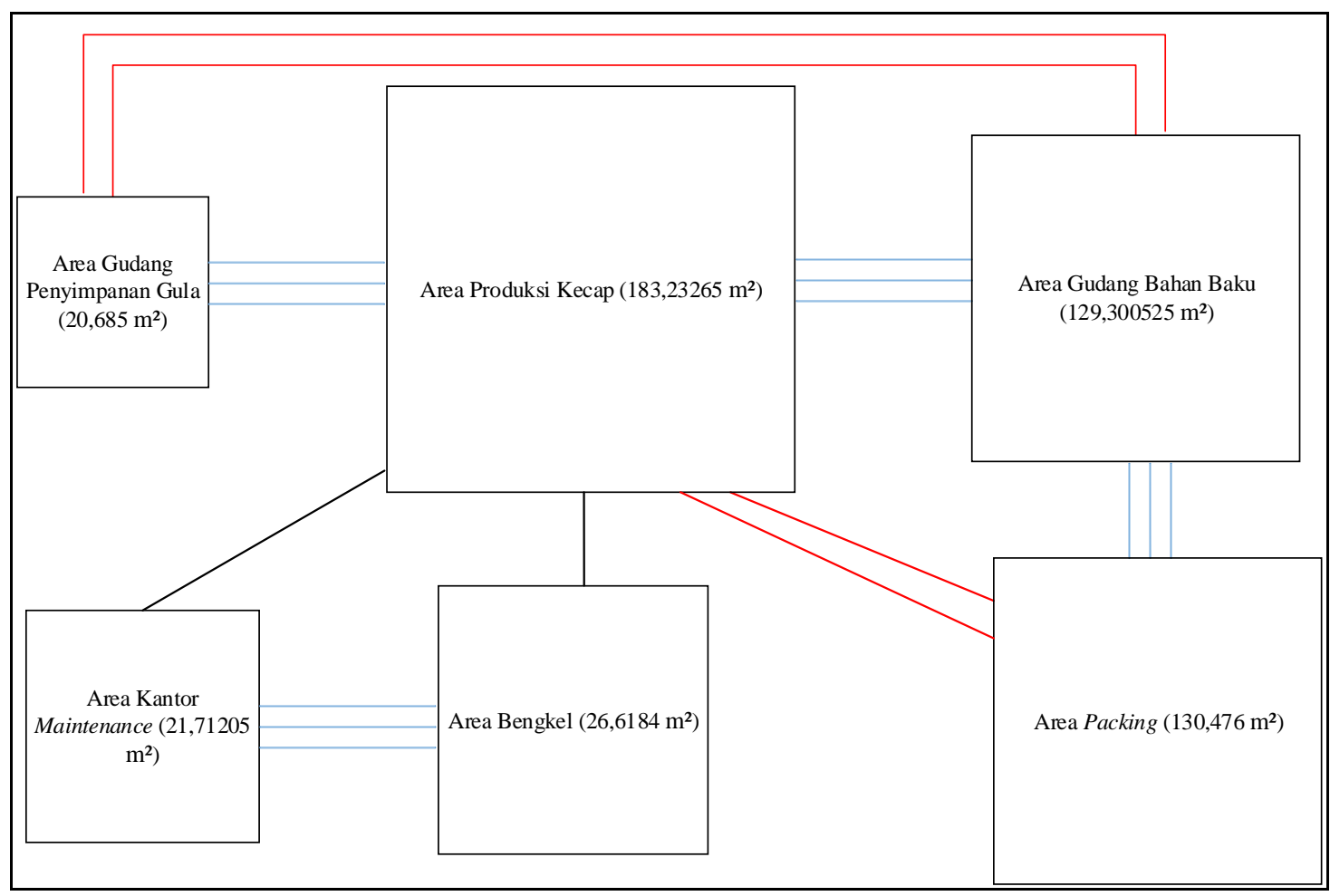

Gambar 11. A RD Usulan II 
PERANCANGAN TATA LETAK LANTAI PRODUKS I B ARU (Retty C. S., dkk)

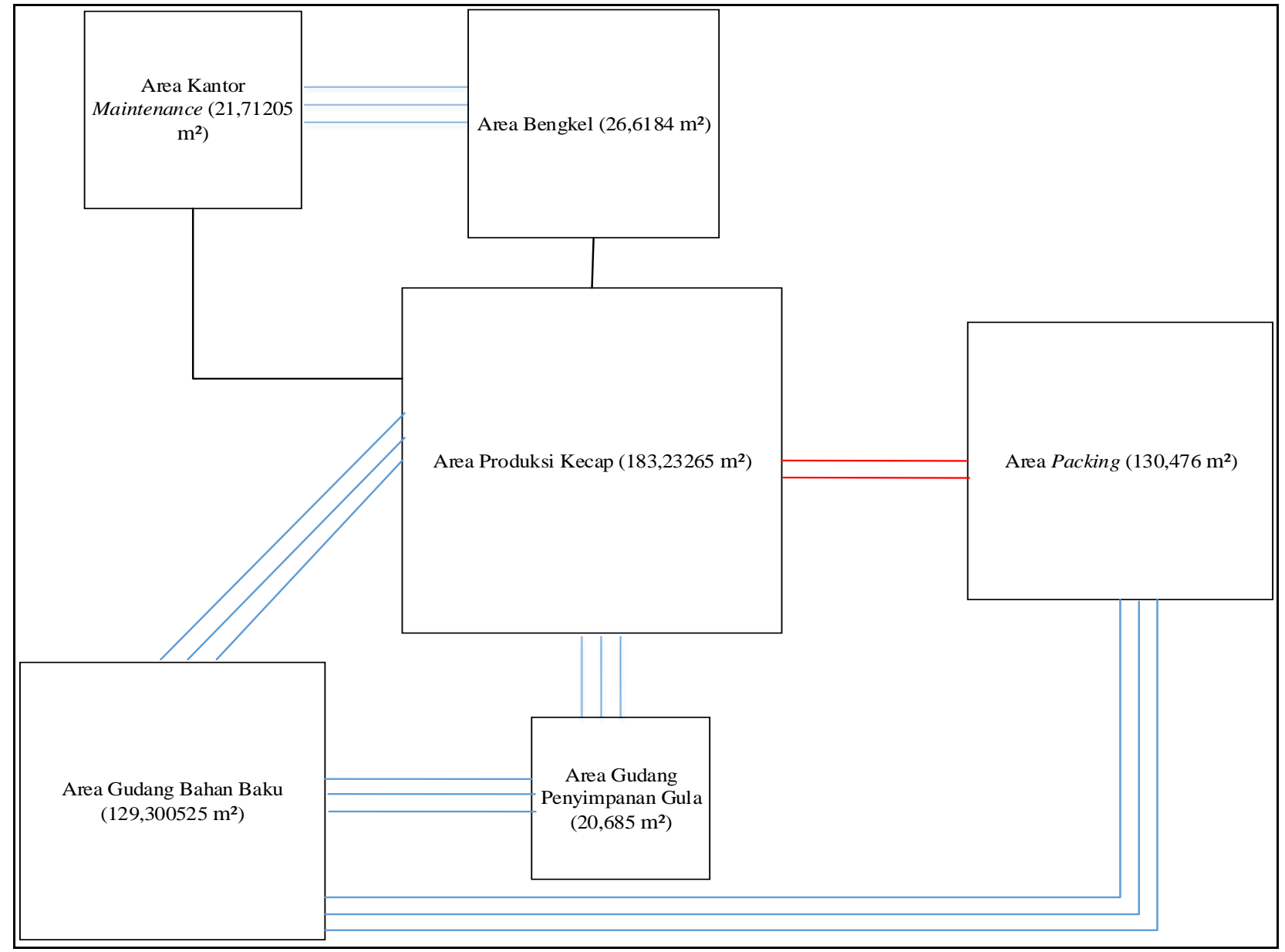

Gambar 12. SRD Usulan III

\subsection{Pertimbangan Modifikasi dan Batasan Praktis}

Pertimbangan modifikasi dan batasan praktis dilakukan supaya dapat menyampaikan hal-hal yang digunakan sebagai pertimbangan dalam melakukan pembuatan alternatif layout usulan.

Tabel 8. Pertimbangan Modifikasi dan Batasan Praktis

\begin{tabular}{|c|c|c|}
\hline No & Pertimbangan Modifikasi & Batasan Praktis \\
\hline 1 & $\begin{array}{c}\text { Belum adanya rancangan layout } \\
\text { pada lokasi yang baru }\end{array}$ & $\begin{array}{c}\text { Membuat rancangan layout } \\
\text { pada lokasi baru }\end{array}$ \\
\hline 2 & $\begin{array}{c}\text { Luas per area lantai produksi } \\
\text { pada lokasi baru belum } \\
\text { ditentukan }\end{array}$ & $\begin{array}{c}\text { Perhitungan luas lantai } \\
\text { produksi dengan menghitung } \\
\text { kebutuhan luas per area }\end{array}$ \\
\hline 3 & $\begin{array}{c}\text { Jarak tempuh aliran material } \\
\text { layout baru belum diketahui }\end{array}$ & $\begin{array}{c}\text { Menghitung jarak tempuh } \\
\text { aliran material antara lokasi } \\
\text { lama dengan yang baru agar } \\
\text { dapat dibandingkan }\end{array}$ \\
\hline
\end{tabular}

\subsection{Pembuatan Alte rnatif Layout Usulan}

Pada tata letak usulan, area yang dimasukkan hanya 7 area yaitu area penyimpanan dan penimbangan ketela, penyimpanan bahan baku dan gula, produksi saus sambal dan manis, produksi kecap, laboratorium, packing, dan kantor produksi. Area kantor maintenance, bengkel, dan toilet tidak diletakkan dalam satu area produksi. Pada area produksi yang baru (yang merupakan area packing tepung tapioka), luas yang dibutuhkan pada tujuh area tersebut adalah $1.056,44255 \mathrm{~m}^{2}$ dari 
JOURNAL OF INTEGRATED S YSTEM VOL 1. NO. 2, DES EMBER 2018: 161-179

luas yang tersedia yaitu $1.140 \mathrm{~m}^{2}$. Pembuatan alternatif layout disertai dengan jarak aliran material yang baru. Berikut adalah alternatif layout usulan:

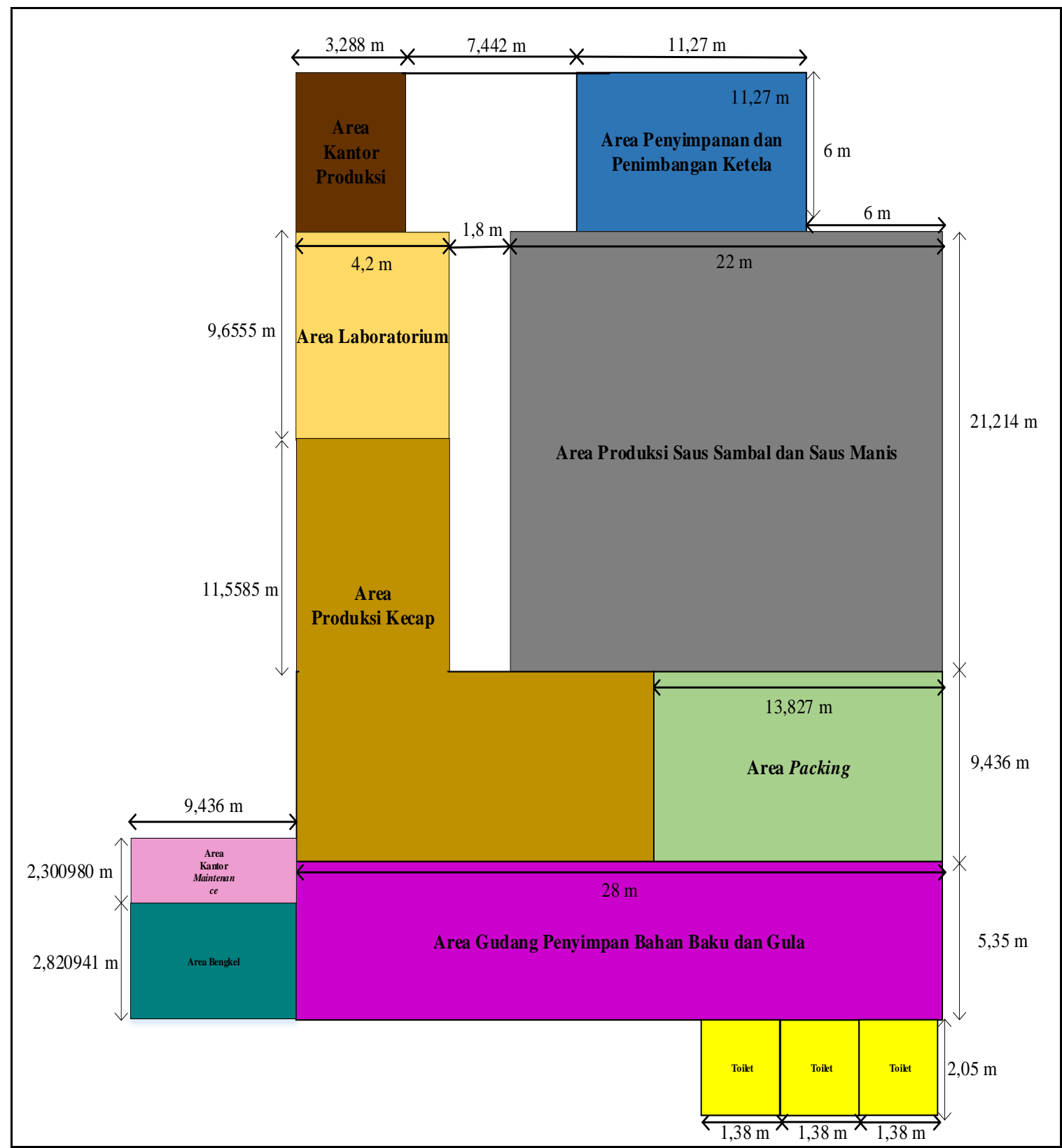

Gambar 13 Alternatif Layout Usulan I

Alternatif layout usulan I memiliki jarak aliran material sebesar 75,0225 m untuk produksi saus dan 80,493 m untuk produksi kecap. 
PERANCANGAN TATA LETAK LANTAI PRODUKS I B ARU (Retty C. S., dkk)

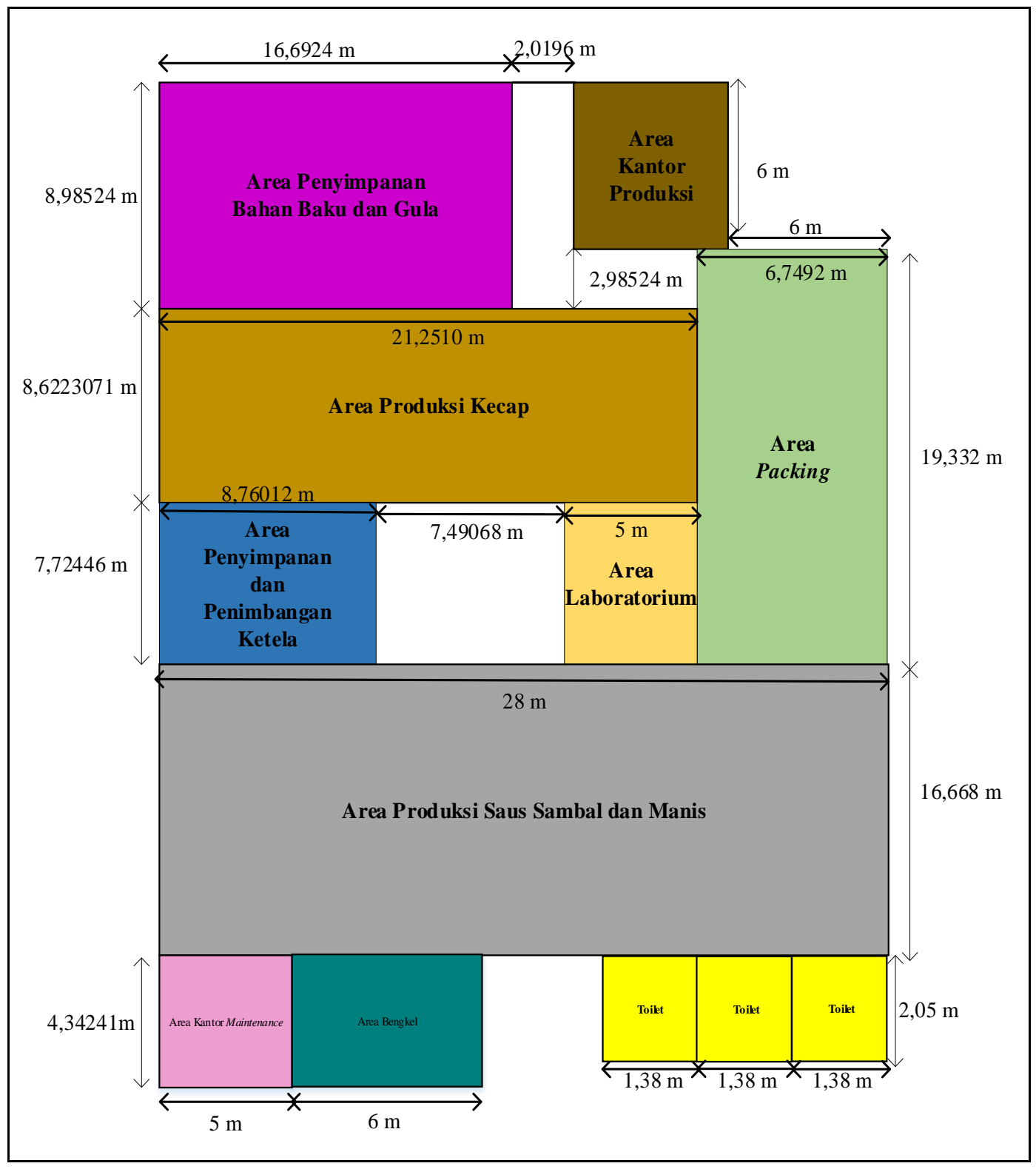

Gambar 14. Alternatif Layout Usulan II

Alternatif layout usulan II memiliki jarak aliran material sebesar $88,33583 \mathrm{~m}$ untuk produksi saus dan 60,0501541 m untuk produksi kecap. 


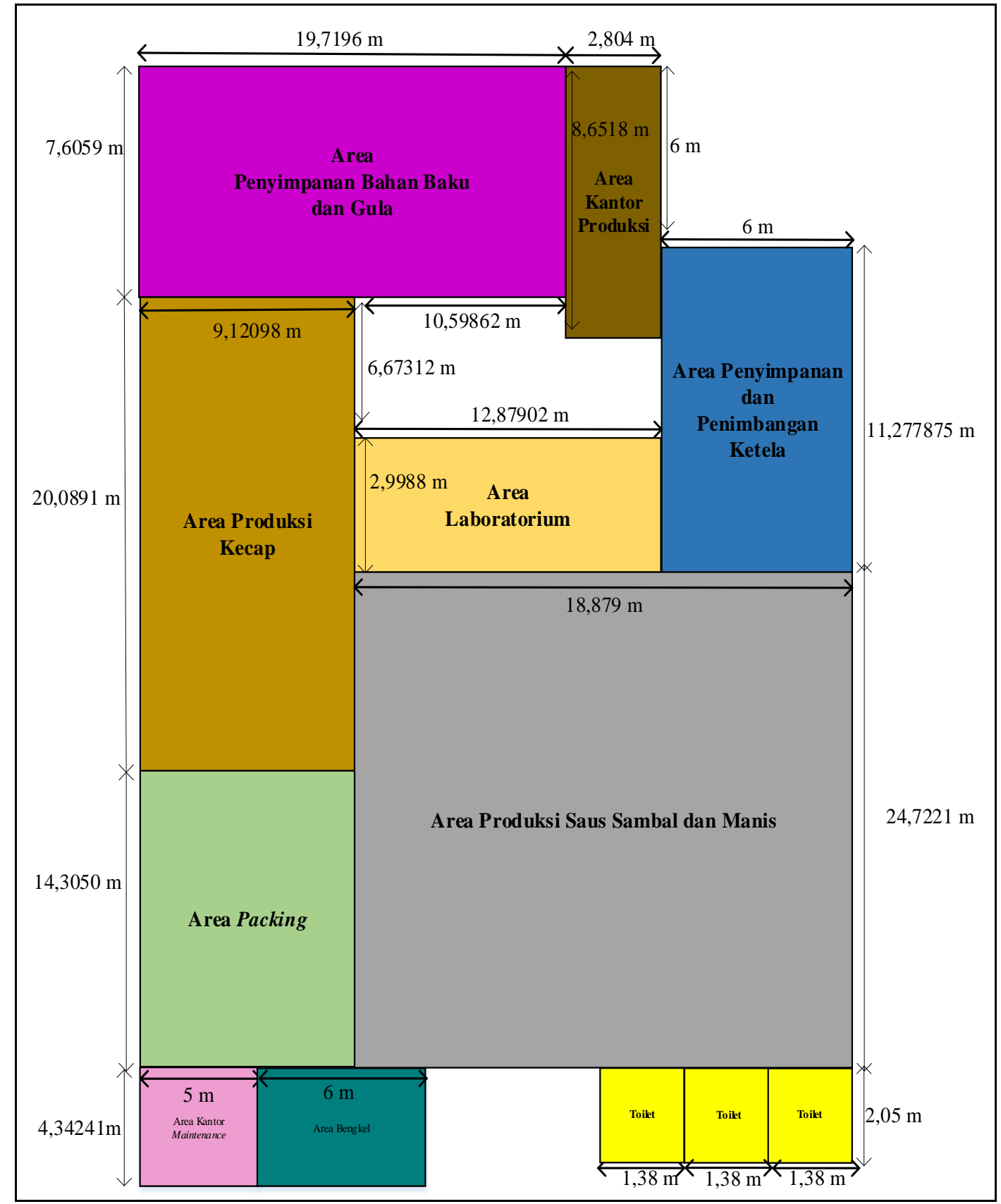

Gambar 15. Alternatif Layout Usulan III

Alternatif layout usulan III memiliki jarak aliran material sebesar 77,3689275 m untuk produksi saus dan 62,08776 m untuk produksi kecap.

\subsection{Evaluasi Alte rnatif Layout Usulan}

Alternatif layout usulan dipilih berdasarkan jumlah jarak aliran material terkecil pada proses produksi saus sambal dan manis serta kecap. Pemilihan layout ini dilakukan supaya dapat mengevaluasi layout yang telah dipilih. Perbandingan jarak aliran material awal dan usulan dari proses produksi saus sambal dan manis serta kecap berdasarkan jarak rectilinear adalah sebagai berikut: 
PERANCANGAN TATA LETAK LANTAI PRODUKS I B ARU (Retty C. S., dkk)

Tabel 9. Perbandingan Jarak A liran Material Awal dan Usulan

\begin{tabular}{|c|c|c|c|c|c|}
\hline No & $\begin{array}{c}\text { Nama } \\
\text { Proses } \\
\text { Produksi }\end{array}$ & $\begin{array}{c}\text { Jarak Aliran } \\
\text { Mate rial } \\
\text { Awal (m) }\end{array}$ & $\begin{array}{c}\text { Jarak Aliran } \\
\text { Mate rial } \\
\text { Usulan I (m) }\end{array}$ & $\begin{array}{c}\text { Jarak Aliran } \\
\text { Material } \\
\text { Usulan II } \\
(\mathbf{m})\end{array}$ & $\begin{array}{c}\text { Jarak Aliran } \\
\text { Material } \\
\text { Usulan III } \\
(\mathbf{m})\end{array}$ \\
\hline 1 & $\begin{array}{c}\text { Saus Sambal } \\
\text { dan Manis }\end{array}$ & 78,53 & 75,023 & 84,336 & 77,369 \\
\hline 2 & Kecap & 108,45 & 80,493 & 60,051 & 62,088 \\
\hline
\end{tabular}

Pada tabel 9 dapat dilihat bahwa meskipun setiap usulan memiliki jarak aliran material yang lebih kecil dibandingkan jarak aliran material awal, aliran material terkecil setiap proses dan usulan berbeda-beda. Alternatif layout usulan II dieliminasi karena jarak aliran material pada saus sambal dan manis > jarak aliran material awal. Pada alternatif layout I dan III, jarak aliran material kecap lebih kecil dibandingkan jarak aliran material kecap pada layout awal. Namun, jarak aliran material kecap pada alternatif layout III jauh lebih kecil dibandingkan dengan layout awal dan alternatif layout II. Oleh karena itu, alternatif layout usulan yang akan dipilih yaitu layout yang memiliki jarak aliran material produksi saus dan kecap yang lebih kecil dibandingkan alternatif layout la innya. Jadi, alternatif layout usulan yang terpilih yaitu layout usulan III.

\section{Kesimpulan dan Saran}

Pada penelitian ini, alternatif layout usulan digambarkan berdasarkan aliran material per proses produksi baik saus maupun kecap. Pembuatan alternatif layout usulan dibuat secara manual dengan memperhatikan kebutuhan luas ruangannya. Alternatif layout usulan yang telah dibuat berjumlah tiga buah rancangan. Terdapat area yang dijadikan satu tempat seperti area penyimpanan bahan baku dan gula meskipun pada lantai produksi awal dijadikan area yang berbeda. Area-area yang menjadi fokus utama dalam pembuatan alternatif layout usulan yaitu area penyimpanan dan penimbangan ketela, laboratorium, produksi saus sambal dan manis, produksi kecap, packing, kantor produksi, serta penyimpanan bahan baku dan gula sehingga luas yang dibutuhkan sebesar $1.056,44255 \mathrm{~m}^{2}$. Area lain yang tidak disebutkan berada di luar area produksi. Alternatif layout usulan memiliki jarak aliran material yang lebih kecil dibandingkan layout lantai produksi saat ini. Hasilnya, dipilihlah alternatif layout usulan III dengan jarak aliran material untuk produksi saus sebesar 77,3689275 m dan produksi kecap sebesar 62,08776 m. CV. Ika Raya Sentausa dapat menggunakan alternatif layout usulan III sebagai salah satu pertimbangan dalam memindahkan lantai produksi saat ini ke area yang baru (area packing tepung tapioka). Jarak aliran material terkecil diharapkan membantu perusahaan dalam meningkatkan produksinya. Selain itu, area kantor maintenance dan gudang sebaiknya tidak diletakkan dalam satu lantai produksi agar proses produksi dapat berjalan lebih lancar.

\section{Daftar Pustaka}

Apple, M.J., (1990), Tata Letak Pabrik dan Pemindahan Bahan, Edisi Ketiga (diterjemahkan oleh: Nurhayati M.T. Mardiono), Penerbit ITB, Bandung.

Chandry, W., (2006), Usulan Block Layout Lantai Produksi dengan Menggunakan Metode CRAFT, CORELAP, dan ALDEP Untuk Meminimasi Biaya Material Handling di PT Aneka Medium Garment, Skripsi, Program Studi Teknik Industri, Universitas Bina Nusantara.

Dewi, D.R.S., Prianto, Y.A., dan Mulyono, J., (2012), "Perbaikan Tata Letak Pabrik dengan Menggunakan Metode Clustering (Studi Kasus: PT SBS)", Prosiding Seminar Nasional Aplikasi Sains dan Teknologi (SNAST) Periode III, Yogyakarta.

Hadiguna, R.A., dan Setiawan H., (2008), Tata Letak Pabrik, Penerbit ANDI, Yogyakarta. 
Muliawan, A.C., (2008), Analisis dan Perancangan Decision Support Untuk Perencanaan Tata Letak Pabrik Pada PT Royalindo Engraftama dengan Menggunakan Metode CRAFT dan ALDEP, Skripsi, Universitas Bina Nusantara.

Naganingrum, R.P., (2012), Perancangan Ulang Tata Letak Fasilitas di PT Dwi Komala dengan Metode Systematic Layout Planning, Skripsi, Jurusan Teknik Industri, Universitas Sebelas Maret.

Susetyo, J., Simanjuntak, R.A., Ramos, J.M., (2010), 'Perancangan Ulang Tata Letak Fasilitas Produksi dengan Pendekatan Group Technology dan Algoritma BLOCPLAN Untuk Meminimasi Ongkos Material Handling”, Jurnal Teknologi, Vol.3, No.1.

Yang, T., Su, C.T., dan Hsu, YR., (2000)," Systematic Layout Planning: A Study on Semiconductor Water Fabrication Facilities", International Journal of Operations and Production Management, Vol. 20, Iss 11, pp. 1359 - 1371.

Yuliarty, P., dan Widiarto, I., (2014), "Perancangan Ulang Tata Letak Lantai Produksi Menggunakan Metode Systematic Layout Planning dengan Software Blocplan pada PT Pindad", Jurnal Ilmiah Teknik Industri, Vol.2, No.3, 159-167. 